\title{
Method for the determining the fuel dose in three-part injection in the CR system of marine combustion engine
}

\begin{abstract}
In this paper authors present the results of their studies on the selection of fuel dose in three-part injection system Common Rail of marine medium-speed combustion engine. The study was conducted on a special test stand, which allows the use of different pressure in the hydraulic tank and various times of injection with doses divided into three parts. Also there has been performed the measurement of single fuel dose mass. The plan of research also included the three values of the two input values (pressure in the hydraulic tank and the total time of injection) and one output - the total mass of the fuel dose. Based on the statistical analysis of measurement results there have been determined the forms of functions approximating the tested relations and have been presented the analysis of the accuracy and their measurements match. Presented polynomials of accuracy (function of researched object) allow a reasonable selection of the basic parameters of dosing for the three-part fuel injection.
\end{abstract}

Key words: common rail system, fuel dosing study, multi-part fuel injection

\section{Metoda określania wielkości dawki trzyczęściowego wtrysku paliwa w systemie CR okrętowego silnika spalinowego}

\begin{abstract}
W pracy autorzy prezentuja wyniki własnych badań dotyczacych doboru dawki w trzyczęściowym wtrysku paliwa w uktadzie Common Rail okrętowego średnioobrotowego silnika spalinowego. Badania przeprowadzono na specjalnym stanowisku badawczym umożliwiającym stosowanie różnych wartości ciśnienia w zasobniku hydraulicznym i różnego czasu wtrysku paliwa przy podziale dawki na trzy części. Wykonywano również pomiar masy pojedynczej dawki. Plan badań obejmował trzy wartości dwóch wielkości wejściowych (ciśnienie w zasobniku hydraulicznym i sumaryczny czas wtrysku paliwa) i jedna wyjściowa - całkowita masę dawki paliwa. Na podstawie analizy statystycznej wyników pomiarów wyznaczono postacie funkcji aproksymujących badane zależności i przedstawiono analizę miar dokładności ich dopasowania. Przedstawione wielomiany dopasowania (funkcje obiektu badań) pozwalaja racjonalnie dobrać podstawowe parametry dawkowania dla trzyczęściowego wtrysku paliwa.
\end{abstract}

Słowa kluczowe: układ common rail, badania dawkowania paliwa, wieloczęściowy wtrysk paliwa

\section{Introduction}

In the construction of a Common Rail (CR) system, which is used in the marine piston combustion engine the important issue is the selection of the dosage, which must take into account, among others the duration of dosage or duration of its parts, engine speed and its load torque.

Marine combustion piston engines are more often equipped with common rail systems, which provide multipart injection fuel delivery to the cylinder. Dose selection must take into account, among others, its duration, the engine speed and load torque. Practical use of a specific fuel dosing is usually preceded by a study on the test stand simulating the injection process and its dependence on the dose parameters.

The authors proposed a method for the selection of these parameters for the medium speed marine engine. This method uses the theory of experiment planning, which allows reducing the number of so-called measurement systems and obtain a mathematical model of the fuel dosing during the injection. The model enables the multi-criteria optimization of the selection of fuel dose and can be used in the design of $\mathrm{CR}$ systems of marine combustion engines.

\section{Wstęp}

W budowie układów typu Common Rail (CR) stosowanych w okrętowych tłokowych silnikach spalinowych istotnym zagadnieniem jest dobór dawkowania, który musi uwzględniać m.in. czas trwania dawki lub jej części, prędkość obrotową silnika i jego obciążenie momentem obrotowym. Praktyczne zastosowanie określonego dawkowania paliwa poprzedza się zazwyczaj badaniami na stanowisku symulującym proces wtrysku i jego zależność od parametrów dawkowania.

Autorzy zaproponowali metodę doboru tych parametrów dla okrętowego średnioobrotowego silnika spalinowego. W metodzie tej wykorzystano teorię planowania eksperymentu, co pozwala uzyskać matematyczny model dawkowania paliwa podczas wtrysku. Model umożliwia wielokryterialną optymalizację doboru dawki i może być wykorzystany w projektowaniu układów CR okrętowych silników spalinowych.

\section{Realizacja eksperymentu}

Przy doborze metody badań uwzględniono właściwości stanowiska badawczego, które jest przeznaczone do pomiaru masy dawki paliwa, ale także, co najważniejsze, rejestracji 


\section{Implementation of the experiment}

In the selection of test methods were included the properties of the test stand, which is designed to measure the mass of fuel dose, but also, most importantly, to record the wave phenomena associated with the fuel supply. Another device used in the construction of the test stand is the controller, which enables the change of pressure in the hydraulic tank and the total time of fuel injection with the assumed distribution times the dose (for the given intervals between each injection of the dose) it is possible to measure the mass of a single dose. The structure of controller allows distributing the fuel dose into five parts. Controller also enables the measurement and recording of the fuel pressure in the manifold, engine speed, fuel temperature in different parts of the supply system, crankshaft angle of injection period which affects on the time conceived to carry out a full dose of fuel per cycle [1].

Using some of the mentioned above features of the test stand the two input values and one output were established - as in the tables 1 and 2. In the further part of the paper there are presented the results of measurement for the case, where a single dose is divided into three parts in the ratio of $10 \%-80 \%-10 \%$, wherein between the pilot dose and the main dose were set the constant time interval equal to 700 $\mu \mathrm{s}$, and between the main dose and additional dose $600 \mu \mathrm{s}$. Due to the low number of input variables (two) and their three values there was adopted a plan of complete static trivalent experiment, which was marked as PS/DK-32 [2].

Results obtained during the measurement allow the determination of approximating functions whose calculations are based on the analysis of variance and provide [3]:

- evaluation of the so called main effects and interactions,

- determining the correlation of the input values and the output values,

- determining the regression coefficients of approximating functions,

- evaluation of the accuracy of the approximation of approximating polynomials.

The software package, which was used to analyze the conducted research with the following models:

- do not take into account the interaction,

- taking into account the linear - linear interaction,

- taking into account the linear - square interaction.

The final decision considering the choice of the model takes an operator familiar with the theoretical basis of the researched problems.

In case of the analyzed experiment the approximating function in the result of the identification may take the fol- zjawisk falowych towarzyszących zasilaniu paliwem. Dodatkowym urządzeniem zastosowanym w budowie stanowiska jest sterownik umożliwiający zmiany ciśnienia w zasobniku hydraulicznym i całkowitego czasu wtrysku paliwa przy założonej krotności podziału dawki (dla danych przerw pomiędzy wtryskiem poszczególnych jej części) oraz pomiar masy pojedynczej dawki. Konstrukcja sterownika umożliwia podział dawki na pięć części. Sterownik umożliwia również pomiar i rejestrację: ciśnienia paliwa w kolektorze, prędkość obrotową silnika, temperaturę paliwa w różnych odcinkach układu zasilania, kąt OWK trwania wtrysku - co przekłada się na czas dysponowany na realizację pełnej dawki paliwa na jeden cykl [1].

Wykorzystując niektóre z wymienionych wyżej możliwości stanowiska badawczego przyjęto dwie wielkości wejściowe i jedną wyjściową - jak w tabelach 1 i 2 . Rozpatrzono przypadek, gdy pojedyncza dawka została podzielona na trzy części w proporcji $10 \%-80 \%-10 \%$, przy czym przyjęto między dawką pilotującą a główną stały odstęp czasowy równy $700 \mu \mathrm{s}$, a między główną i dodatkową $600 \mu \mathrm{s}$. Z uwagi na niewielką liczbę wielkości wejściowych (dwie) i ich trzy wartości przyjęto plan doświadczenia statyczny kompletny trójwartościowy oznaczany PS/DK-32 [2].

Uzyskane w trakcie pomiarów wyniki pozwoliły na określenie funkcji aproksymujących, których obliczenia opierają się na analizie wariancji i zapewniają [3]:

- ocenę tzw. efektów głównych i interakcji;

- wyznaczenie korelacji wielkości wejściowych z wyjściowymi;

- wyznaczenie współczynników regresji funkcji aproksymujących;

- ocenę dokładności przybliżenia wielomianów aproksymujących.

Wykorzystany do analizy pakiet oprogramowania przeprowadzenie badań z użyciem następujących modeli:

- nie uwzględniających interakcji;

- z uwzględnieniem interakcji liniowo - liniowych;

- z uwzględnieniem interakcji liniowo - kwadratowych.

Ostateczną decyzję co do wyboru modelu podejmuje operator znający podstawy teoretyczne badanego zagadnienia.

W przypadku analizowanego eksperymentu funkcja aproksymująca $\mathrm{w}$ wyniku przeprowadzonej identyfikacji może mieć następujące postacie w zależności od rodzaju uwzględnionej interakcji:

- bez uwzględnienia interakcji - wzór (1),

- z uwzględnieniem interakcji liniowo - liniowych - wzór (2),

- z uwzględnieniem interakcji liniowo - kwadratowych wzór (3).

Table 1. The comparison of the input values

Tabela 1. Zestawienie wartości wielkości wejściowych

\begin{tabular}{|c|c|c|c|c|c|}
\hline $\begin{array}{l}\text { No./ } \\
l p .\end{array}$ & $\begin{array}{l}\text { Name of the input value/nazwa wielkości } \\
\text { wejściowej }\end{array}$ & $\begin{array}{l}\text { Marking and dimension/ } \\
\text { oznaczenie } i \text { wymiar }\end{array}$ & $\begin{array}{l}\text { Low value/ } \\
\text { wartość dolna }\end{array}$ & $\begin{array}{l}\text { Average value/ } \\
\text { wartość średnia }\end{array}$ & $\begin{array}{l}\text { High value/ } \\
\text { wartość górna }\end{array}$ \\
\hline 1 & $\begin{array}{l}\text { Pressure in the hydraulic tank/ciśnienie w zasob- } \\
\text { niku hydraulicznym }\end{array}$ & $\mathrm{p}_{\mathrm{z}}[\mathrm{MPa}]$ & 120 & 135 & 150 \\
\hline 2 & $\begin{array}{l}\text { Total time of injection/sumaryczny czas wtrysku } \\
\text { paliwa }\end{array}$ & $\mathrm{t}\left[\mathrm{s}^{-6}\right]$ & 2300 & 3000 & 3700 \\
\hline
\end{tabular}


Table 2. Plan of the experiment and the results of measurements of fuel delivery

Tabela 2. Plan doświadczenia $i$ wyniki pomiarów dawki paliwa

\begin{tabular}{|c|c|c|c|}
\hline $\begin{array}{c}\text { Number of measurement system/ } \\
n r \text { uktadu pomiarów }\end{array}$ & $\mathrm{p}_{\mathrm{z}}[\mathrm{MPa}]$ & $\begin{array}{c}\text { Total time of injection/ } \\
\text { sumaryczny czas wtrysku }\left[\mathrm{s}^{-6}\right]\end{array}$ & \begin{tabular}{c} 
Fuel dose/ dawka pal. [mg/inj] \\
\hline 1
\end{tabular} \\
\hline 2 & 120 & 3700 & 141.84 \\
\hline 3 & 120 & 3000 & 92.16 \\
\hline 4 & 135 & 3700 & 142.48 \\
\hline 5 & 135 & 3000 & 95.12 \\
\hline 6 & 135 & 2300 & 52.28 \\
\hline 7 & 150 & 3700 & 144.92 \\
\hline 8 & 150 & 3000 & 99.18 \\
\hline
\end{tabular}

lowing forms depending on the type of interaction that is included:

- without taking into account the interaction

$$
\begin{aligned}
& \mathrm{q}=-76.14-0.0211 \cdot \mathrm{p}_{\mathrm{z}}-0.0007 \cdot \mathrm{p}_{\mathrm{z}}^{2}+ \\
& -0.0425 \cdot \mathrm{t}+0.0000038 \cdot \mathrm{t}^{2}
\end{aligned}
$$

- taking into account the linear - linear interaction

$$
\begin{aligned}
& q=-93.89+0.1103 \cdot p_{z}+0.000696 \cdot p_{z}^{2}+ \\
& +0.0484 \cdot t+0.0000038 \cdot t^{2}+ \\
& -0.0000438 \cdot p_{z} \cdot t
\end{aligned}
$$

- taking into account the linear - square interaction

$$
\begin{aligned}
& \mathrm{q}=-1015.9+15.695 \cdot \mathrm{p}_{z}-0.0636 \cdot \mathrm{p}_{z}^{2}+ \\
& +0.5702 \cdot \mathrm{t}-0.000065 \cdot \mathrm{t}^{2}-0.0091 \cdot \mathrm{p}_{\mathrm{z}} \cdot \mathrm{t}+ \\
& +0.00000124 \cdot \mathrm{p}_{\mathrm{z}} \cdot \mathrm{t}^{2}+0.0000381 \cdot \mathrm{p}_{\mathrm{z}}^{2} \cdot \mathrm{t}+ \\
& -0.000000005 \cdot \mathrm{p}_{\mathrm{z}}^{2} \cdot \mathrm{t}^{2}
\end{aligned}
$$

In the above mentioned polynomials were set the regression coefficients, in which the significant numbers occur on distant decimal places, but their product with the specified parameters results in values, which are significant for the study.

To assess the reliability of the analysis included in the adopted above models of multiple regression was made for a review of the results of the unconverted output value. The results indicate that for the model without the interaction and with linear - linear interaction the significant importance for tests indicate the components of linear equations. For example, the probability of obtaining the random result $\mathrm{p}$ for the above components of equation does not exceed 0.015 , the value of the t-Student's distribution is well above the minimum values for the accepted number of degrees of latitude and $p<0.05$. Analysis of the equation of regression with the linear - square interaction of is not statistically significant $\left(\mathrm{R}^{2}>1\right.$ - which is in contrary to the definition of the coef-
W podanych wyżej wielomianach wyznaczono współczynniki regresji, w których liczby znaczące występują wiele miejsc po przecinku, jednak ich iloczyn z podanymi parametrami daje $\mathrm{w}$ wyniku wartości znaczące dla prowadzonej analizy.

Do oceny wiarygodności analiz uwzględnionych w przyjętych wyżej modelach regresji wielokrotnej został dokonany przegląd wyników dla nieprzekształconej wielkości wyjściowej. Wyniki wskazują na to, że dla modelu bez interakcji i z interakcją liniowo - liniową największą istotność testów wykazują liniowe składniki równań. Dla przykładu prawdopodobieństwo uzyskania przypadkowego wyniku $p$ dla powyższych składników równań nie przekracza 0,015, wartość rozkładu t-Studenta znacznie przekracza minimalne wartości dla przyjętej liczby stopni swobody i p $<0,05$. Analiza modelu równania regresji z interakcją liniowo - kwadratową nie jest istotna statystycznie $\left(\mathrm{R}^{2}>1\right.$ - co jest sprzeczne $\mathrm{z}$ definicją współczynnika determinacji) - o czym świadczą wielkości i miary oceny zamieszczone w tabeli 3.

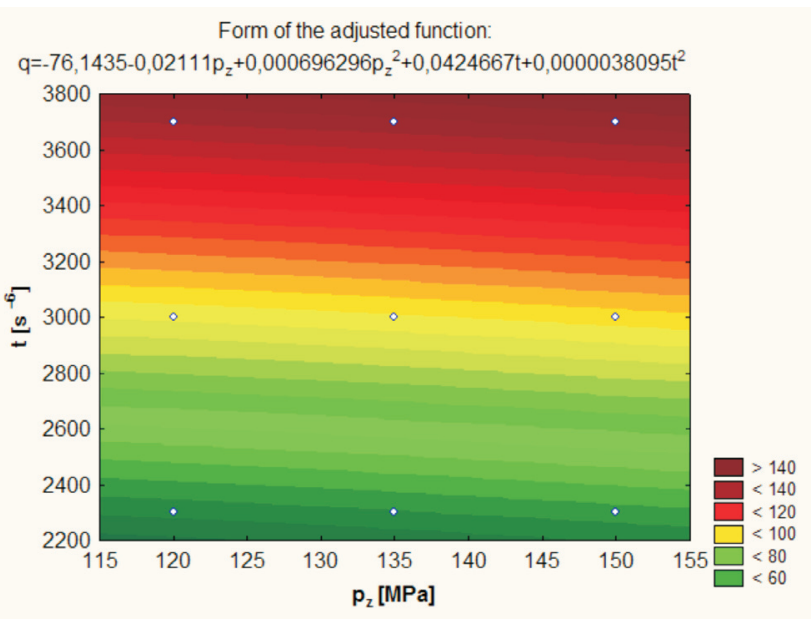

Fig. 1. Contour plot of prediction of fuel dose per cycle, depending on the pressure in the hydraulic tank and the total time of fuel injection for the estimation using a model without the interaction

Rys. 1. Wykres warstwicowy predykcji dawki paliwa na cykl w zależności od ciśnienia $w$ zasobniku hydraulicznym i sumarycznego czasu wtrysku paliwa przy estymacji z wykorzystaniem modelu bez interakcji 
Table 3. The summary of specific values and evaluations of fitting the function of research object describing the fuel delivery

Tabela 3. Zestawienie charakterystycznych wielkości i miar oceny dopasowania funkcji obiektu badań opisującej dawki paliwa

\begin{tabular}{|c|c|c|c|c|c|}
\hline \multirow[t]{2}{*}{ No./lp. } & \multirow{2}{*}{\multicolumn{2}{|c|}{ Value/wielkość }} & \multicolumn{3}{|c|}{ Model } \\
\hline & & & \multirow{2}{*}{$\begin{array}{c}\text { without the interaction/ } \\
\text { bez interakcji } \\
-0.02111111 \\
\end{array}$} & \multirow{2}{*}{$\begin{array}{c}\text { with the linear - linear interac- } \\
\text { tion/ } z \text { interakcjami liniowo- } \\
\text { liniowymi }\end{array}$} & \multirow{2}{*}{$\begin{array}{c}\begin{array}{c}\text { with the linear - square interac- } \\
\text { tion/ } \mathrm{z} \text { interakcjami liniowo- } \\
\text { kwadratowymi }\end{array} \\
15.694816360\end{array}$} \\
\hline 1 & Regression & $\mathrm{p}_{\mathrm{z}}$ & & & \\
\hline & $\begin{array}{l}\text { coefficient/ } \\
\text { wspótczynnik }\end{array}$ & $\mathrm{p}_{\mathrm{z}}^{2}$ & 0.00069630 & 0.00069630 & -0.063623583 \\
\hline & regresji $\mathrm{b}_{\mathrm{i}}$ & $\mathrm{t}$ & 0.0425 & 0.04838095 & 0.570216328 \\
\hline & & $\mathrm{t}^{2}$ & 0.00000381 & 0.00000381 & -0.000065184 \\
\hline \multirow[t]{4}{*}{2} & \multirow{4}{*}{$\begin{array}{c}\text { Average estima- } \\
\text { tion error of the } \\
\text { parameter/s'redni } \\
\text { bład szacunku } \\
\text { parametru } \mathrm{S}_{\mathrm{bi}}\end{array}$} & $\mathrm{p}_{\mathrm{z}}$ & 0.969734037 & 1.03940 & - \\
\hline & & $\mathrm{p}_{\mathrm{z}}^{2}$ & 0.00359 & 0.00379 & - \\
\hline & & $\mathrm{t}$ & 0.00991 & 0.01304 & - \\
\hline & & $\mathrm{t}^{2}$ & 0.00000165 & 0.00000 & - \\
\hline \multirow[t]{4}{*}{3} & \multirow{4}{*}{$\begin{array}{l}\text { The quotient/ } \\
\quad \text { iloraz } \\
\mathrm{t}=\mathrm{b}_{\mathrm{i}} / \mathrm{S}_{\mathrm{bi}}\end{array}$} & $\mathrm{p}_{\mathrm{z}}$ & -0.02177 & 0.10614 & - \\
\hline & & $\mathrm{p}_{\mathrm{z}}^{2}$ & 0.19396 & 0.18351 & - \\
\hline & & $\mathrm{t}$ & 4.28396 & 3.71049 & - \\
\hline & & $\mathrm{t}^{2}$ & 2.31101 & 2.18652 & - \\
\hline 4 & \multicolumn{2}{|c|}{ Total residual/ suma reszt $\mathrm{MS}$} & 1.304844 & 1.457659 & - \\
\hline 5 & \multicolumn{2}{|c|}{$\begin{array}{l}\text { Determination coefficient/ } \\
\text { wspótczynnik determinacji } \mathrm{R}^{2}\end{array}$} & 0.99959 & 0.99965 & 1.002 \\
\hline
\end{tabular}

ficient of determination) - which is proven by the values and evaluations of measures presented in Table 3.

Contour graphs (Fig. 1 and 2) allow predicting the fuel delivery per injection in the change intervals $\mathrm{p}_{\mathrm{z}}$ and $\mathrm{t}$ exemplary given in the figures. For example, for $\mathrm{p}_{\mathrm{z}}=140$ $\mathrm{MPa}$ and $\mathrm{t}=3300 \mu$ s the estimated fuel dose according to the model without the interaction is equal to $\mathrm{q} \_\mathrm{bi}=116.2$ $\mathrm{mg} / \mathrm{LGP}$, and to the model with the linear - linear interaction is q_ll $=116.11 \mathrm{mg} / \mathrm{inj}$.

On the dispersion graphs (Fig. 3, 4, and 5) are presented relations of the fuel dose per injection on respectively: fuel pressure in the hydraulic tank, the total time of injection for the considered fuel dose and kinematic viscosity of fuel used in the research on the test stand. It should be clarified that although the change of kinematic viscosity was not taken into account in the planning of the experiment, this change of kinematic viscosity affects on the value of fuel dose at the given pressure $\mathrm{p}_{\mathrm{z}}$ and time of injection $\mathrm{t}$. To build the considered graphs there have been used the results of measurements of fuel dose on the test stand and the values of fuel, which were obtained as a result of its prediction using the models used for the analysis. The figures contain the equations of adjustment straights of considered results of both measurements and prediction. The forms of equations indicate that the initial three straight run very close to each other, or even overlap, while the fourth significantly differs from them - which confirm the earlier remarks of the statistical insignificance of the adopted model of the linear - square interactions.

A measure of the mutual influence of the various independent variables on the dependent variable, and their relationship is the angle between averaging straight and the $\mathrm{x}$-axis. As can be seen from the graphs in Figure 6 and the conducted analysis the most powerful influence on the
Wykresy warstwicowe (rys. 1 i 2 ) pozwalają przewidywać dawkę paliwa na wtrysk w podanych przykładowo na rysunkach przedziałach zmian $\mathrm{p}_{\mathrm{z}}$ i t. Na przykład dla $\mathrm{p}_{\mathrm{z}}=140$ MPa i t $=3300 \mu$ s estymowana dawka paliwa wg modelu bez interakcji wynosi q bi $=116,2 \mathrm{mg} / \mathrm{wtr}$, a $\mathrm{z}$ interakcją liniowo - liniową q $11=116,11 \mathrm{mg} / \mathrm{wtr}$.

$\mathrm{Na}$ wykresach rozrzutu (rys. 3, 4, i 5) przedstawiono zależności dawki paliwa na wtrysk od - odpowiednio - ciśnienia paliwa w zasobniku hydraulicznym, sumarycznego czasu wtrysku rozpatrywanej dawki i lepkości kinematycznej paliwa użytego do badań na stanowisku laboratoryjnym. Należy wyjaśnić, że co prawda zmiana lepkości nie była

Form of the adjustment of function:

$q=-93,8863+0,110317 p_{z}+0,000696296 p_{z}{ }^{2}+0,04838095 t+0,00000380952 t^{2}$ $-0,0000438095 p_{z} t$

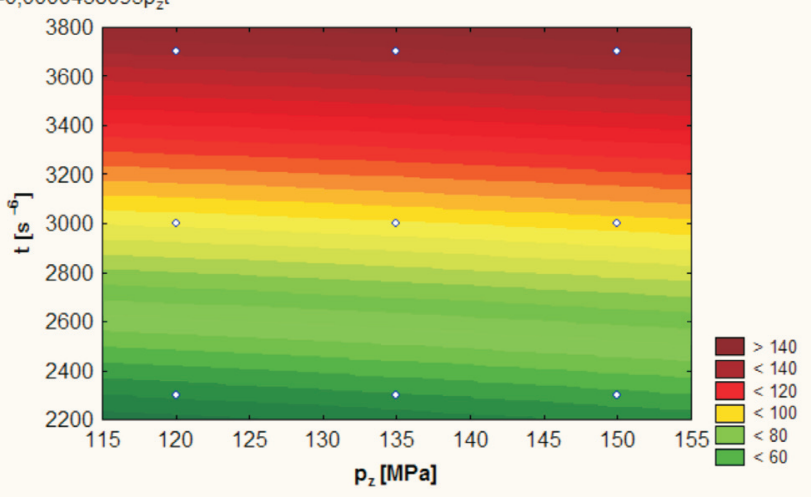

Fig.2. Contour plot of prediction of fuel dose per cycle, depending on the pressure in the hydraulic tank and the total time of fuel injection for the estimation using a model with the linear - linear interaction

Rys. 2. Wykres warstwicowy predykcji dawki paliwa na cykl w zależności od ciśnienia w zasobniku hydraulicznym i sumarycznego czasu wtrysku paliwa przy estymacji z wykorzystaniem modelu z interakcjami liniowo - liniowymi 


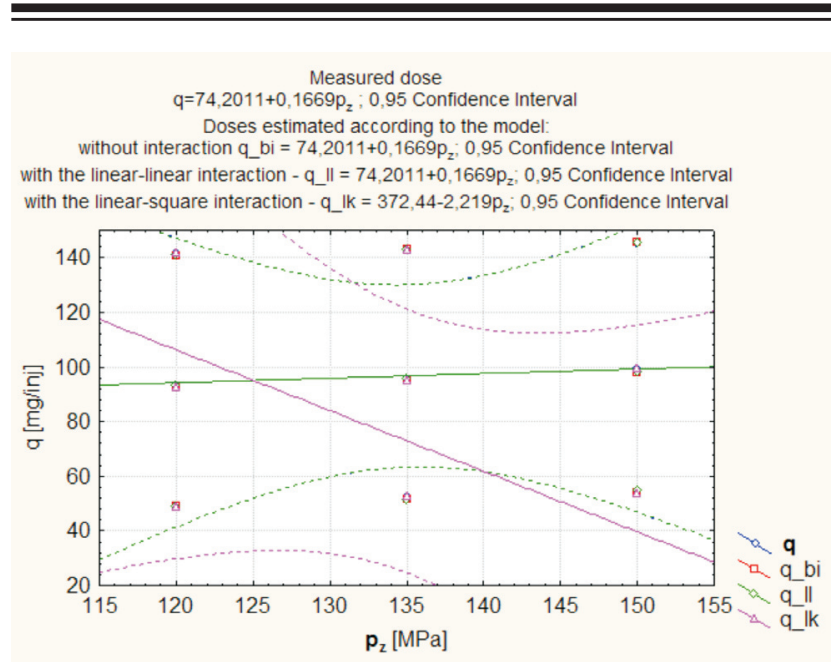

Fig. 3. The comparison of measured and estimated doses of fuel depending on the model of function (function of researched object) as a function of pressure in the tank $\mathrm{p}_{z}$

Rys. 3. Porównanie dawek paliwa pomierzonej i estymowanych w zależności od przyjętego modelu (funkcji obiektu badań) jako funkcji ciśnienia $w$ zasobniku $p_{z}$

change of fuel dose has total time of injection (the correlation coefficient $\mathrm{R}=0.998)$, little importance has the change of

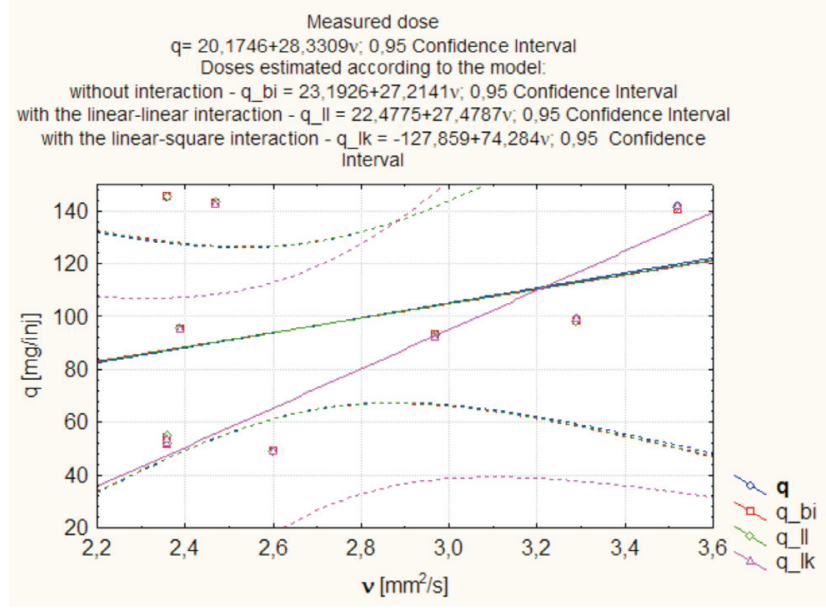

Fig. 5. The comparison of measured and estimated doses of fuel depending on the model of function (function of researched object) as a function of kinematic viscosity $v$

Rys. 5. Porównanie dawek paliwa pomierzonej i estymowanych $w$ zależności od przyjętego modelu (funkcji obiektu badań) jako funkcji lepkości kinematycznej $\mathrm{v}$

pressure in the tank $\mathrm{p}_{\mathrm{z}}(\mathrm{R}=0.0546)$, and the fairly influence on the value of mass of fuel dose has the kinematic viscosity $v(\mathrm{R}=0.319)$, which was not considered in the planning of experiment.

\section{Summary and conclusions}

Summarizing the above considerations related to the modeling of the fuel dosing with applying to the research on the size of fuel dose for different fuel supply options in the Common Rail systems of the medium-speed marine engine can be concluded that:

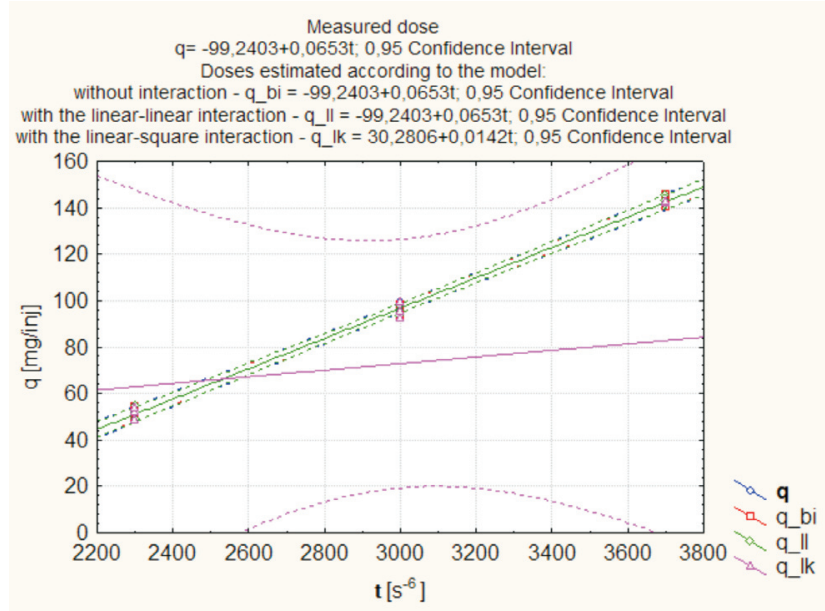

Fig. 4. The comparison of measured and estimated doses of fuel depending on the model of function (function of researched object) as a function of injection time $\mathrm{t}$

Rys. 4. Porównanie dawek paliwa pomierzonej i estymowanych w zależności od przyjętego modelu (funkcji obiektu badań) jako funkcji czasu wtrysku $t$

uwzględniana w planowaniu eksperymentu, to jednak zmiana lepkości kinematycznej wpływa na wielkość dawki przy danym ciśnieniu $\mathrm{p}_{\mathrm{z}}$ i czasie wtrysku t. Do budowy rozpatrywanych wykresów wykorzystano wyniki pomiarów dawki paliwa na stanowisku badawczym oraz wartości dawki paliwa uzyskane w rezultacie ich predykcji przy użyciu zastosowanych do analizy modeli. Na rysunkach zamieszczono równania prostych dopasowania rozpatrywanych wyników zarówno pomiarów jak i predykcji. Postaci zamieszczonych równań wskazują na to, że początkowe trzy proste przebiegają bardzo blisko siebie albo wręcz się pokrywają, natomiast czwarta znacznie od nich odbiega - co potwierdza wcześniejsze spostrzeżenia o nieistotności statystycznej przyjętego modelu z interakcjami liniowo - kwadratowymi.

Miarą wzajemnego wpływu poszczególnych zmiennych niezależnych na zmienną zależną i ich wzajemnych relacji jest kąt nachylenia prostej uśredniającej do osi odciętych. Jak wynika z wykresów na rys. 6 i przeprowadzonej analizy najsilniejszy wpływ na zmianę dawki paliwa ma całkowity czas wtrysku paliwa (współczynnik korelacji $\mathrm{R}=0,998$ ), niewielkie znaczenie ma zmiana ciśnienia $\mathrm{w}$ zasobniku $\mathrm{p}_{\mathrm{z}}$ $(\mathrm{R}=0,0546)$, dość duży wpływ na wielkość masy dawki paliwa ma nierozpatrywana $\mathrm{w}$ planowaniu doświadczenia lepkość kinematyczna $\vee(\mathrm{R}=0,319)$.

\section{Podsumowanie i wnioski}

Podsumowując powyższe rozważania związane z modelowaniem dawkowania $\mathrm{z}$ zastosowaniem do badania wielkości dawki paliwa dla różnych wariantów zasilania paliwem w układach Common Rail średnioobrotowego silnika okrętowego można stwierdzić, że:

1. Zastosowanie elementów planowania eksperymentu zapewnia wysoką efektywność realizacji założonego zakresu badań, a także skrócenie czasu ich trwania oraz obniżenie kosztów. 
1. Applying the elements of planning the experiment ensure the high efficiency of achieving the planned scope of research, as well as shortening their duration and reducing the costs.

2. Among the approximating functions applied in the analysis the statistically significant were functions applying the model without the interaction and function applying the model with the linear - linear interaction. Function applying the model, which is taking into account the linear square interaction was statistically insignificant.

3. The accuracy of the approximation of approximating polynomials
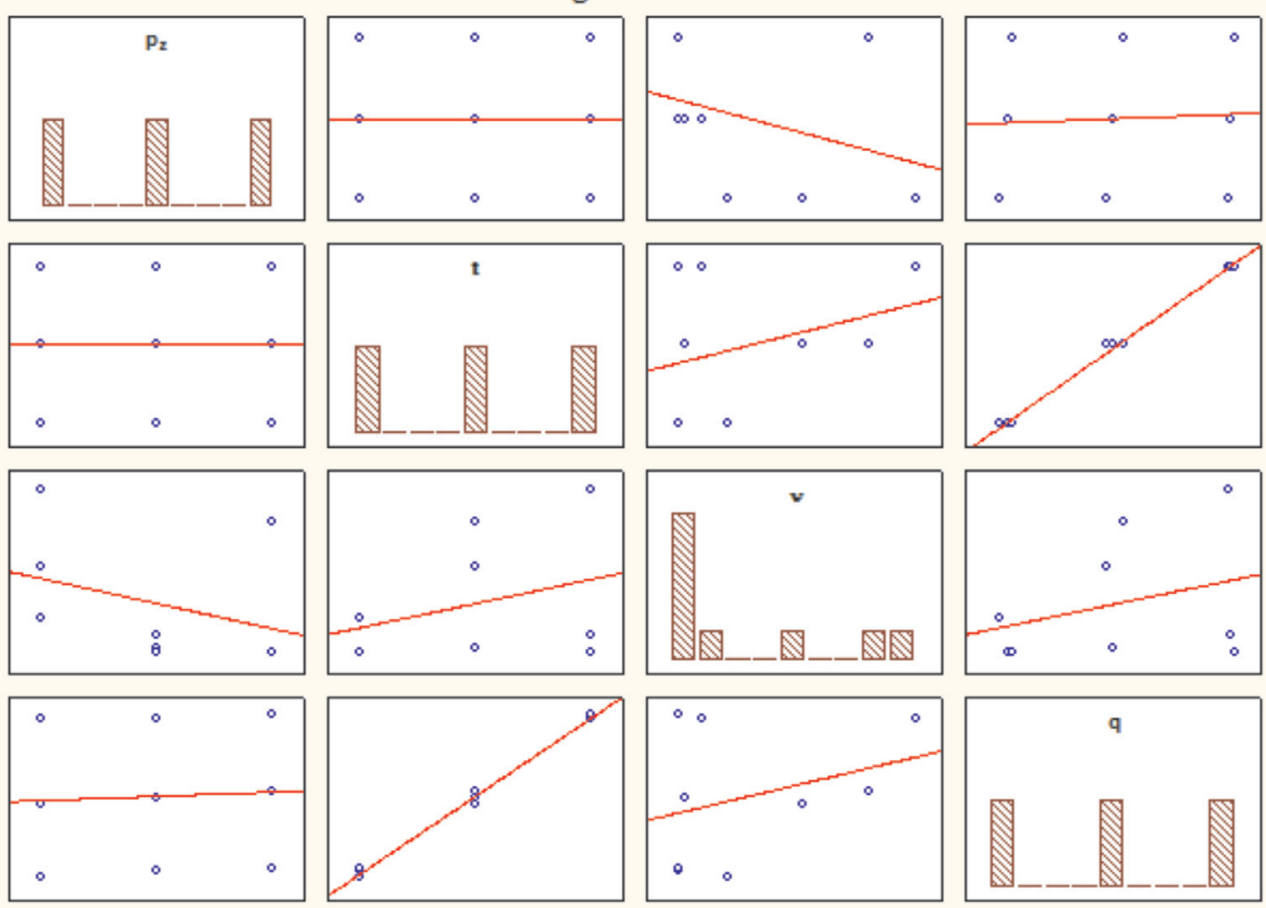

Fig.6. Correlation of mutual dependent variable $\mathrm{q}$ (a single dose of fuel) and the independent variables $\mathrm{p}_{\mathrm{z}}, \mathrm{t}, \mathrm{v}$ (respectively, pressure in the hydraulic tank, the total time of injection, kinematic viscosity)

Rys. 6. Wykres korelacji wzajemnych zmiennej zależnej q (jednorazowa dawka paliwa) i zmiennych niezależnych $p_{z}$, t, v (odpowiednio: ciśnienie w zasobniku hydraulicznym, sumaryczny czas wtrysku, lepkość kinematyczna) accepted as statistically significant does not exceed the established five percent of confidence interval.

4. A fairly significant impact of the changes of kinematic viscosity leads to the conclusion that in the further analyzes of this type mentioned parameter must be taken into consideration.
2. Spośród wykorzystanych do analizy funkcji aproksymujących istotne statystycznie okazały się funkcje z użyciem modelu bez interakcji i funkcja $\mathrm{z}$ użyciem modelu $\mathrm{z}$ interakcji liniowo - liniowych. Funkcja z użyciem modelu z uwzględnieniem interakcji liniowo - kwadratowych okazała się nieistotna statystycznie.

3. Dokładności przybliżenia wielomianów aproksymujących przyjętych jako istotne statystycznie nie przekroczyła założonego pięcioprocentowego przedziału ufności.

4. Dość znaczny wpływ zmian lepkości kinematycznej skłania do wniosku, że przy kolejnych tego typu analizach należy uwzględnić ten parametr.

\section{Bibliography/Literatura}

[1] Piaseczny L., Walkowski M.: Simulation studies of selected characteristics of the injection system the common rail medium-speed research engine. Combustion Engines, No. 4/2012 (151).

[2] Korzyński M.: Metodyka eksperymentu. WNT, Warszawa 2006.

Prof. Leszek Piaseczny, DSc, DEng. - Professor in the Mechanical-Electric Faculty at Naval University of Gdynia.

Prof. $d r$ hab. inż. Leszek Piaseczny - profesor na Wydziale Mechaniczno-Elektrycznym Akademii Marynarki Wojennej w Gdyni. e-mail:piaseczny@ptnss.pl
[3] Chłopek Z., Piaseczny L.: Zastosowanie teorii planowania doświadczeń w badaniach ekologicznych właściwości silników spalinowych. Archiwum Motoryzacji, 2002, No. 2-3, pp. 6993.

[4] Statistica PL dla Windows: Tom IV - Statystyki przemysłowe. StatSoft Polska. Kraków 1997.

Mirosław Walkowski, DEng. - member of the PSSCE.

Dr inż. Mirosław Walkowski-czlonek PTNSS.

e-mail:mwal@interia.eu

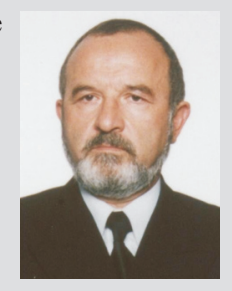

